\title{
MONETARY POLICY PASS-THROUGH, EXCESS LIQUIDITY AND PRICE SPILLOVER: A COMPARATIVE STUDY OF CONVENTIONAL AND ISLAMIC BANKS OF PAKISTAN
}

\author{
Muhammad Omer \\ State Bank of Pakistan, Pakistan, muhammad.omer@sbp.org.pk
}

\begin{abstract}
This study investigates the comparative pass-through of policy rate to the retail prices, spillover of prices between Islamic and conventional banking systems, and the impact of excess liquidity on these pass-throughs using data from interbank market of Pakistan. The results suggest that the monetary policy shock affect retail prices of Islamic banks similar to conventional banks, confirming the results of earlier studies. Moreover, there is a strong spillover between the prices of two systems; Islamic banks are following (leading) the conventional banks in pricing the lending (deposit) products. Islamic bank has acquired advantage in the deposit pricing by taping the religious depositors, which also may have promoted financial inclusion thereby contributing to the economic growth and improved income distribution in the society. Our findings suggest that the presence of excess liquidity have no effect on passthrough of policy rate in the Islamic system, which is contrary to the prevalent notion. However, excess liquidity significantly affects the spillovers of prices between the systems. These results support the hypothesis that the Islamic banks are investing in interest-based government securities indirectly via conventional banks. Our findings may help in enhancing the regulatory efficiency of the central banks and the conduct of the monetary policy in the countries where dual banking system exists.
\end{abstract}

Keywords: Excess Liquidity, Islamic Banks, Monetary Policy Pass-Through, Pakistan, VECM, Mediation.

JEL Classification: E42; E52; E58.

Article history:

Received : September 14, 2018

Revised : April 08, 2019

Accepted : April 08, 2019

Available online : July 30, 2019

https://doi.org/10.21098/jimf.v5i2.1064 


\section{INTRODUCTION}

Literature on Islamic finance is preoccupied with assessment of monetary policy effectiveness in a hybrid system, where both Islamic and conventional banks coexist, by assessing specific channel(s) in spirit of conventional monetary transmission mechanism. Such an assessment, however, requires a number of factors specific to the Islamic financial system, such as presence of excess liquidity, prohibition of interest payments and price spillover from conventional to the Islamic financial system, to be taken into account (Khatat, 2016). Specially, in presence of price spillover, the central bank's ability to make precise impact on the market condition may be compromised if the financial system includes a welldeveloped interest rate channel but less developed Islamic financial system. The latter may become conduit to the conventional monetary transmission, though such price transmission through Islamic banks may not be expected by the regulators due to Sharia restriction. In this situation, differentiated policy tools, if adopted by the central bank for the two systems, may become less effective in regulating the market conditions.

At the same time, strong presence of Islamic banks could activate credit channel of monetary policy transmission as long as the central bank's actions affect the supply of Islamic credit (Khatat, 2016). Presence of excess liquidity, in either case, may weaken the monetary policy transmission as it effect the ability of the banks to price their retail products effectively. ${ }^{1}$ This subject has acquired more importance with the rapid growth of Islamic banking in the global financial landscape, as excess liquidity apparently is a permanent feature of Islamic financial system. Islamic banks have limited investment opportunities since financial instruments complying Sharia restrictions are not in abundance. ${ }^{2}$ Furthermore, Islamic banks cannot participate in the interbank market directly, where banks transact mostly in Repo using non-Sharia compliant instruments. Neither, it can place excess reserve with the central bank to earn minimum return wherever central banks provide standing facilities for liquidity management through interest rate corridors. It is not surprising that a majority of the Islamic banking scholars surveyed by Iqbal (1998) opined that the excess liquidity was a serious problem for some or all Islamic banks.

In addition, the presence of excess liquidity in Islamic system may distort the conventional interbank rates despite the fact that former is expected to remain isolated from the conventional one. Interbank market of Pakistan has experienced this phenomenon in recent past, where overnight call rates frequently swung to discount, from premium to the repo rate, under the influence of Islamic banks' excess liquidity. ${ }^{3}$ Such a distortionary effect may have repercussions for transmission of policy shocks, not only through conventional banks but also through Islamic banks.

\footnotetext{
1. Even in the conventional system, presence of excess liquidity may impede monetary policy passthrough thereby disturbing the retail products' pricing mechanism [for detail see, Aryeetey (1998), Agénor et al. (2004), Saxegaard (2006)].

2. By Shari'ah laws, Islamic banks are required to invest in instruments free of Riba (interest), Gharar (uncertainty), Maisir (gambling) and non-Halal (prohibited) activities.

3. For more details, see Section 2.
} 
This study, therefore, assesses the effectiveness of monetary policy transmission by incorporating the excess liquidity present in both systems using the interest rate channel only, as the realization of this channel is stronger in Pakistan compared to other channels. Moreover, Islamic banking enjoys a minor share in Pakistan, which makes interest rate channel more interesting for study. In this perspective, this research attempts to answer two key questions; first, how excess liquidity effect the pass-through of the policy rate to the retail rates (rents/investments) in the two systems? ${ }^{4}$ Second, how excess liquidity effect the price spillover between the two systems? The answers to the questions will improve our understanding of transmission mechanism, and will help in formulation of effective monetary policy not only in Pakistan, but also in other countries where hybrid financial system exists.

This paper contributes to the literature in a number of ways. First, the impact of excess liquidity has hardly been empirically assessed before for the Islamic banking system. Existing literature on conventional system investigated this impact, but only qualitatively, inferring it as obstructive if coefficient is negative. ${ }^{5}$ Our study provides the quantitative estimates not only for Islamic system but also for the conventional banking system. Second, this paper divulges into the spillover effect of retail rate adjustments between the conventional and the Islamic systems. To the best of our knowledge, very few studies [including Bacha (2004), Chong and Liu (2009) and Cevik and Charap (2011) and Ben Amar et al. (2015)] have assessed this effect. Moreover, the role of excess liquidity as conduit for these spillovers has been assessed thoroughly for the first time. Lastly, this research used separate retail rates for the conventional and Islamic banks for analysis. Previous work on conventional transmission mechanism used the aggregate retail rates, including that offered/paid by the Islamic banks. Therefore, estimates of those studies reflect the dynamics of overall banking system, even if the motive was to study the transmission mechanism in the conventional banking system.

This paper uses Vector Error Correction Mechanism (VECM) for assessing monetary policy pass-through separately for the two systems, and spillover of prices between them. To assess the impact of liquidity on the transmission mechanism and on the price spillover between the systems, mediator- moderator approach is used. Data from January 2004 to October 2016 is used for analysis. Our findings, which confirm previous studies, suggest that the monetary policy shock affects the retail prices of the Islamic banks similar to the conventional banks. Moreover, there is strong spillover of prices between the systems; Islamic banks are following (leading) the conventional banks in pricing the lending (deposit) products.

Apparent advantage gained by Islamic banks in deposit pricing could be due to inflow of untapped religious deposits suggesting that the advent of the Islamic banks have promoted the financial inclusion in Pakistan. Literature [Khan (2010), Ming-Hua Liu (2009) and Obaidullah (2005) Ariss (2010)] suggests that Islamic

4. The terminology of rent and investment rate is used to imply the Islamic banks equivalence for lending and deposit rates in the conventional banks.

5. Notable studies reporting the impact of excess liquidity on monetary policy pass-through are Nissanke and Aryeetey (1998), Agénor et al. (2004), Saxegaard (2006), Sorensen and Warner (2006), Lucchetta (2007), Egert and MacDonald (2009), and Gigineishvili (2011). 
banks generally follow the conventional banks in setting prices of the retail products, specifically the deposits, as the former faces the 'deposit withdrawal risk'. Our findings show that it is other way around in Pakistan. Conventional banks, being the price taker in the deposit market suffers from the 'deposit withdrawal risk'. For a long time, conventional banks in Pakistan have enjoyed low deposit rate, as investment opportunities available to the retail investors were limited. This may have changed since the inception of Islamic finance.

In response to key research questions, our results indicate that presence of excess liquidity impedes the pass-through of policy rate significantly in conventional banks, but insignificantly in the Islamic banks; the latter being contrary to the findings of Iqbal (1998). The assessment of impact of excess liquidity on the price spillover suggests that the excess liquidity with the Islamic banks mostly mediates this process. In case of shock to the lending price equilibrium, the Islamic excess liquidity declines, and resurfaces as a conventional excess liquidity in the long run. It is important to note that the excess liquidity with the Islamic banks remains mostly in fungible cash reserves form with the central bank. On the contrary, the conventional excess liquidity remains mostly in the form of short-term government securities, as the central bank frequently intervenes in the interbank market for absorption, if this liquidity is more than desired by the central bank. The results endorse the possibility of the liquidity transmission from Islamic banks via conventional banks to the interest based short-term government securities.

The rest of the study is structured as follows. Chapter 2 divulge into the structure of Islamic banking in Pakistan besides presenting the review of recent literature on this subject. Chapter 3 discusses data and methodology. Chapter 4 elaborates on the results and finally Chapter 5 concludes with policy discussion.

\section{LITERATURE REVIEW}

\subsection{Perspective of Islamic Finance and its Structure in Pakistan}

Doing business in Islamic way requires Muslims to undertake transactions free of Riba (interest), Gharar (uncertainty), Maisir (gambling) and non-Halal (prohibited) activities. Islamic banks are, therefore, forbidden from taking or offering interest or usury. Unlike in conventional banking, a lender in Islamic finance should shares the risk of the project with the borrower, as neither the borrower nor lender controls the outcome of the venture. This risk sharing in financial contracting by replacing ex-ante fixed return, with an ex-post uncertain return based on a profitsharing principle, differentiates Islamic from conventional banking. Under this profit and loss sharing (PLS) paradigm, only the profit-sharing ratio between the financer and borrower is determined ex-ante (Chong and Liu, 2009).

In practice, however, Islamic finance institutions offers both PLS and non-PLS products. A financier could opt for direct equity stake, based on participatory financing (or PLS), or non-participatory financing (or non-PLS) with no take on equity (Khan, 2010). The important participatory forms are Mudaraba, and Musharaka. In former contract, a 'sleeping' partner contributes capital while active partner contributes expertise/knowledge. In latter contract, a financier also participates into the activities of the venture. Important non- participatory financing form includes Murabaha ('markup' or cost-plus sale), Ijara (lease), Bay' 
salam/Istisna (deferred delivery), Bai muajjal (deferred payment), Jo'alah (service fee), and Qard al hasana (charity/beneficence loan). ${ }^{6}$

A large number of institutions offer interest free banking based on Islamic products in predominantly Muslim, as well as, in non- Muslim countries. Only Iran, Pakistan, and Sudan are referred to as countries with full Islamic banking. Pakistan's inclusion in this group is surprising and deceptive as well. Despite PLS banking introduced in Pakistan in 1980s, banks never shared losses with the depositors neither their depositors received any share in the windfall profits, which the banks in Pakistan are making (Khan, 2008). Moreover, the contract these banks are making with their client are based on ex-ante fixed rate and are benchmarked with the interbank market or policy rate, which makes them conventional instead of PLS based Islamic banks. This study, therefore, treats all scheduled banks in Pakistan as conventional banks. Moreover, only designated Islamic banks established following the recommendation of Commission for Transformation of Financial System (CTFS) and Pakistan's Supreme Court ruling in June 2002 as the Islamic. ${ }^{7}$ Since the 2002, State Bank of Pakistan issued licenses for Sharia compliant Islamic banks only, with their own Sharia board that ensures its operational consistency with Sharia requirements.

Table A1, in Appendix, provides an overview of the banking sector of Pakistan; which consists of five public sector commercial banks, 32 local private banks, four foreign banks and four specialized banks. Foreign banks are mostly in non-retail businesses while specialize banks are active in development finance. These specialized banks are meant to support the long term growth objectives of government and are, therefore, excluded from the definition of commercial banks. Besides, there are a number of microfinance banks actively promoting financial intermediation. However, the balance sheet size of these microfinance banks is very small compared to the conventional and/or Islamic banks. Table A2 in Appendix, on the other hand, demonstrates the composition of the Islamic banking industry. Islamic banking services provided by six full fledge Islamic banks, and sixteen Branch Islamic banks owned by the conventional banks. These Branch banks operate as a subsidiary of conventional banks, and are required to undertake the financial transactions in accordance with the injunctions of Sharia.

\section{Price determination in conventional and Islamic banks}

The banking literature has extensively provided the conjectured explanations of interest rate's influence on pricing of the Islamic products. For example, El Gamal (2006) argues that the Islamic product has to be functionally identical to the conventional product since otherwise it would not be approved by banking regulators in both Islamic and non-Islamic countries. Moreover, Khan (2010), Ming-Hua Liu (2009) and Obaidullah (2005) Ariss (2010), argues that Islamic finance competes with the conventional banks and often follows the conventional banks while setting the prices of their retail products. Following sub-section

6. For details, see Khan (2010), Chong and Liu (2009), Baele et al. (2014).

7. The Commission for Transformation of Financial System (CTFS) was established on $1^{\text {st }}$ order of SAB-SC (January 2000) on appeal against ruling of Supreme Court's Shari'at Appellate Bench of December 1999. 
provides a brief overview of the comparative price setting mechanism in banking sector of Pakistan.

SBP regulation requires conventional banks to price their products with reference to certain benchmarks. For example, lending rate is required to be linked with the relevant tenure Karachi Interbank Offered Rates (KIBORs) ${ }^{8}$ and deposit rate with the SBP Repo rate (i.e., floor of SBP Interest rate Corridor). ${ }^{9}$ As Islamic banks has yet to develop their own benchmark for lending purposes, the SBP instructions on pricing of lending products (via BPD Circular 01, 2004) remains the guiding framework for loaning business for Islamic banks' as well. Nevertheless, products based on participatory financing (Musharakah, Mudarabah and Wakalah) is exempted from KIBOR benchmarking. ${ }^{10}$

Pricing of the deposits is more complicated in Islamic banking system. Unlike conventional banks, Islamic banks are not required to benchmark the deposit pricing with the SBP Repo rates. On contrary, Islamic banks are required to share their profits from financings, investments and placements with the depositors, as their deposit mix is mostly Mudaraba based. Islamic banks in Pakistan pool funds from depositors similar to asset management companies. ${ }^{11}$ These pools are identified by their risk and reward features. Each pool works like a virtual enterprise having explicitly demarcated sources of funds, ownership of specific assets, and income and expenses. ${ }^{12}$

Other factors, such as Profit Sharing Ratio (PSR), Profit Equalization Reserves (PER) and transfer from Mudarib to the depositors as Hiba (or gift) also influences the retail price (or profit rate) a depositor ultimately receives. Islamic bank, as a Mudarib, has to agree with the depositor (Rabbulmal) on the Profit Sharing Ratio (PSR) for distribution of the same between them. Moreover, for profit smoothening purposes, an Islamic bank is allowed to create a Profit Equalization Reserve (PER) with well-defined criteria from net income of Pool (i.e. the gross income less direct expenses and losses, if any). ${ }^{13}$

Islamic banks are allowed to utilize, fully or partly, the amount of PER to improve the returns to the depositors during periods when the pool's profits are below market expectations. Furthermore, the former may forego up to 60 percent

8. Banks \& DFIs should use the Karachi Interbank Offered Rate (KIBOR) of one, three \& six-month, and other longer tenors, as made available, for pricing of all Rupee Corporate/Commercial bank lending (Vide BPD Circular No. 01, 2004).

9. Vide BPRD Circular No. 07, 2013. Before, the banks were required to pay minimum deposit rate prescribed by the central bank from June 1, 2008.

10. Vide IBD Circular No. 01, 2016.

11. In this contract, Islamic bank is known as Mudarib and their depositors are known as Rabbulmal, and profit sharing ratio is to be agreed between the parties right from beginning of the contract.

12. For detailed instruction on profit \& loss distribution, see IBD Circular No. 03 of 2012. Unlike in an asset management companies where all cost has to be charged to the profit earned, only direct expenses like depreciation of Ijarah assets, cost of sales of inventories, insurance / Takaful expenses of pool assets, stamp fee or documentation charges, brokerage fee for purchase of securities/ commodities, and impairment/losses due to physical damages to specific assets is chargeable to the pool in the Islamic banking system. Beside, all indirect cost including the establishment cost is to be borne by the Islamic bank, as a Mudarib.

13. The monthly contribution into PER will not exceed 2 percent of Net Income, and the accumulated balance of PER shall not exceed 30\% of Islamic Bank's Equity or Islamic Banking Fund (IBF) of Islamic Banking Division of Conventional banks. 
of its Mudarib share as Hiba (or gift) to meet the market expectation in case of lower than expected/market return earned by the pool. However, Islamic banks maintaining PER may reduce their (Mudarib's) share, using Hiba, only if the reserve is insufficient to improve the profit payouts to the depositors.

Despite this elaborate framework, Islamic banks have been blamed for exploiting PSR, PER and Hiba only to enhance their competitiveness with the conventional banks. Khan (2010) argues that no Islamic Bank has ever charged its depositor's accounts when it incurred losses due to increased non-performing assets. On the contrary, Islamic Banks often declared market-competitive returns for depositors even when running into financial difficulties. Moreover, sometimes central bank's implicit guarantee on Islamic Bank deposits, as practiced in GCC counties, also goes against the very basics of the risk sharing principle of Islamic banks.

\section{Excess liquidity: A comparative perspective of Pakistan's banking}

Excess liquidity is often defined as the excess reserve of banks, placed with the central banks, over and above the statutory requirements (such as Cash Reserve Requirement (CRR) and/or Statutory Liquidity Requirement (SLR)). ${ }^{14}$ Literature (including Agénor et al., 2004; Ruffer and Stracca, 2006; Saxegaard, 2006; and Gigineishvili, 2011) defines excess liquidity as a ratio of reserves deposited with the central bank by the banks and cash in their vault. However, banks in Pakistan holds substantial amount of government securities, which are as liquid as cash and provides risk free returns to the holders. Therefore, following Mohanty et al. (2006), these eligible government securities are included in the definition of excess liquidity for this research. ${ }^{15}$

Conventional banks in Pakistan have invested heavily in government securities specifically in last decade when the economy was experiencing a slowdown. Generally, banks park their excess liquidity in treasury bills for short term and in Pakistan Investment Bonds (PIBs) for long term, when credit demand slows down or deceleration in economic activity increases expected default risk (Omer at al., 2015). ${ }^{16}$ Studies by Nissanke and Aryeetey (1998), Agénor et al. (2004), Saxegaard (2006), Sørensen and Warner (2006), Lucchetta (2007), Egert and MacDonald (2009), and Gigineishvili (2011) suggest that the presence of excess liquidity impedes conventional monetary policy transmission. Like in conventional banks, excess liquidity present in the Islamic system remains a subject of controversy for the policy makers and researchers alike, as its impact remains yet to be assessed.

Apparently, Islamic banks invests only in Government Ijarah Sukuk (GIS); a Sharia Compliant Islamic financial instrument. However, volume and frequency of

14. CRR requires banks to deposits a certain part of cash held with the central bank. As per SLR, banks are required to invest a certain part of deposits into the government securities.

15. Thus excess liquidity is defined as the ratio of reserves deposited with the central bank by the banks, cash in their vault and eligible government securities, in excess of the statutory limit to the total time and demand liabilities of the banks.

16. At the top of that conventional banks parks excess fund with the central banks using the central bank's interest rate corridor facility. Banks receives SBP Repo rate (floor of corridor) on their reserve placement with central bank. 
issues of GIS by the government is very low compared to its demand from Islamic banks. Moreover, Islamic banks cannot park their excess funds with central bank using interest rate corridor, as these facilities are not incompliance with Sharia requirements. Given the limited investment opportunity, Islamic banks often live with excess liquidity that could unexpectedly spillover to the conventional system in a number of ways.

Figure 1.

Transmission of Excess Liquidity from Islamic to Conventional Banks

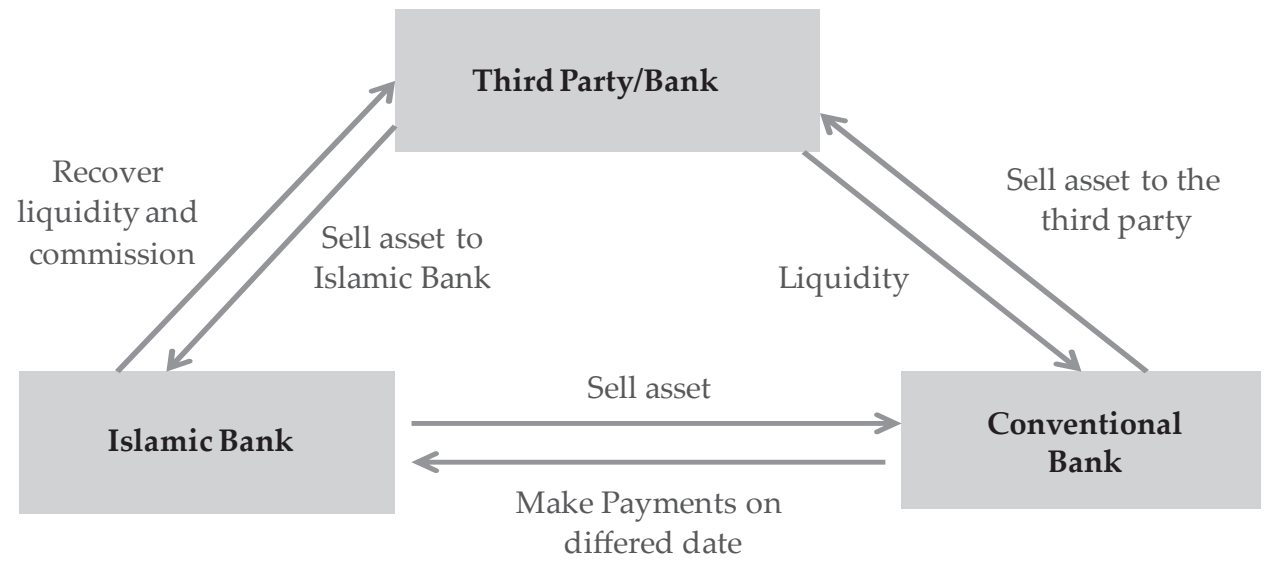

Figure 1 indicates one such possibility. In this arrangement, an Islamic bank may sell an asset, typically an Ijarah Sukuk to a borrowing bank at a deferred price. The borrowing bank sells this asset to another bank and raises cash liquidity for its own use. The Islamic bank replenishes its security holding from the market (or perhaps from third bank) besides parking liquidity for a specific tenure. As deal matures, the borrowing bank repays cash to the Islamic bank with agreed profit. ${ }^{17}$

Pakistan's interbank market has witnessed such liquidity spillover effect since 2008, as Call market rate frequently slipped below Repo rate in overnight money market (Figure 2). Call rate is a price of unsecure lending/borrowing between the banks in interbank market while repo is a rate on secured lending/borrowing. Theoretically, call rate should be above the Repo rate because of risk premium attached to the unsecured lending. The negative premium (discount) on the call rate suggests that excess liquidity in the call market is distorting price setting mechanism in the interbank market. Therefore, a persistent arbitrage opportunity was present in the market; where a bank can earn an arbitrage profit by borrowing in call market and lending in repo market.

17. Islamic banks generally report the transactions as 'clean' or 'call' lending. This kind of arrangement, however, requires three banks to materialize. The third bank also seeks 'rent' to get involved in this activity which often depresses the rate received by the Islamic banks. 
Figure 2.

Monthly Average Money Market Rates

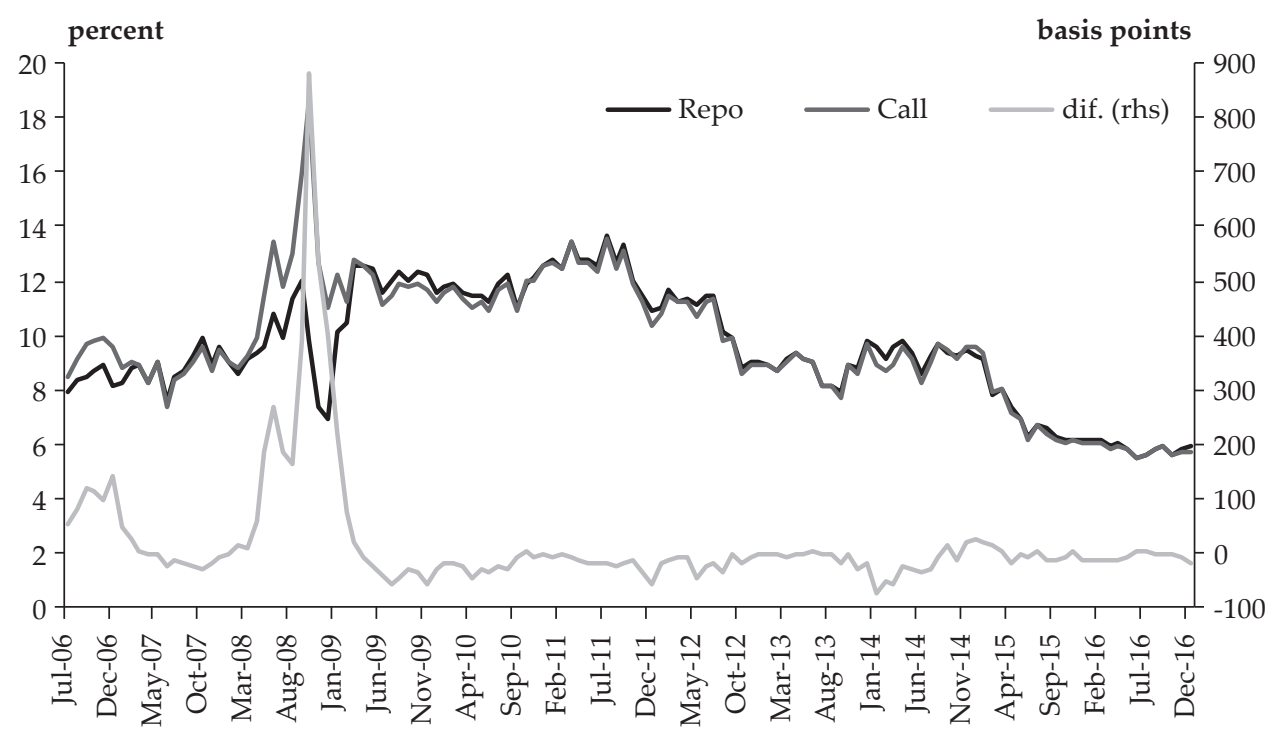

\subsection{A Review of Recent Literature}

Hypothetically, Islamic banks should be indifferent to the changes in the interest rates, as they rely on interest-free banking. Therefore, bank lending channel attained greater importance for studying the transmission of policy shocks in Islamic banks. Not surprisingly, a large number of studies investigated the country specific bank lending channel such as, [Aysan et al. (2017), Ergec and Arslan (2013), and Macit (2012)] for Turkey, [Caporale et al. (2016), Akhatova (2016), Asbeig and Kassim (2015) and Hasin and Majid (2015)] for Malaysia, Sukmana (2015), Ben Amar et al. (2015) and Zaheer (2013) respectively for Indonesia, Saudi Arabia and Pakistan. Such studies consensually arrived at the similar conclusion using different sample periods that monetary policy shocks affect the lending of the Islamic banks similar to that in the conventional banks.

In a nutshell, Aysan et al. (2017) found that in Turkey, bank lending decreases with the increase in the policy rate because depositor move their deposit to higher return offering banks. These authors also observed that responses of deposits and credits to monetary shocks were larger for Islamic banks. Similarly, for Turkey, Macit (2012) reported a difference in response between conventional and participation banks to monetary policy shocks using quarterly loan growth. In this study, the participation banks showed larger reaction to monetary policy. In terms of bank specific variables, however, banks with higher liquidity ratio tend to had higher loan growth whereas banks with larger asset size had smaller loan growth.

In case of Malaysia, Hasin and Majid (2015) confirmed that Islamic banking was not spared from the interest rate and monetary conditions of the country. Moreover, both Akhatova (2016) and Caporale et al. (2016) found a significant response from conventional bank credit and Islamic bank financing to monetary policy shocks. However, the dynamic behavior of Islamic banks following 
monetary policy shocks, as well as other shocks, appears to be different. On the contrary, Asbeig and Kassim (2015) found that changes in the monetary policy had no significant impact on the level of financing extended by the Islamic and conventional banks. However, bank-specific factors, namely size and liquidity influenced the lending behavior of both the Islamic and conventional banks, whereas capitalization was relevant only for the Islamic banks.

Sukmana (2015) examined the sensitivity of the economic sectors in response to the change in the Islamic and conventional monetary policy rate in the Indonesian economy. Their results indicated that the Islamic banks play important roles in channeling the monetary transmission. Both Hasin and Majid (2015) and Sukmana (2015) confirmed that specific economic sectors react differently to the Islamic and conventional monetary instruments. Ben Amar et al. (2015) investigated the effectiveness of monetary policy transmission in Saudi Arabia's Islamic banks and reported that bank lending channel is relatively effective in influencing non-oil private output, but less effective in influencing consumer prices. Zaheer (2013) also analyzed the differences in banks' responses to monetary policy shocks across conventional and Islamic banks in Pakistan by incorporating bank size, liquidity, and type. Their result showed that Islamic banks cut their lending less than other small banks with liquid balance sheets, following a monetary contraction.

Though bank lending was the most anticipated channel for transmission of the policy shocks in Islamic banks, a large number of studies [Chong and Liu (2009), Ergec and Arslan (2013), Khan (2010), Hasin and Majid (2015), Akhatova (2016), Husin (2015), Zaheer (2013) and Husman (2015)] documented that Islamic banks functioning is noticeably influenced by interest rate changes. As Khatat (2016) argued, the Islamic banks may become conduit to the conventional monetary transmission in presence of well-developed interest rate channel but less developed Islamic financial system. The subsequent section discusses a number of studies arguing for the influence of interest rate on the retail pricing of Islamic banks.

For example, Chong and Liu (2009), Husman (2015) and Husin (2015) assessed the influence of the interest rate on the rent/profit on Islamic lending/deposit using interest rate channel of the monetary policy. Specifically, Chong and Liu (2009) found influence of the interest rate on the volume of lending/deposits of the Islamic banks in Malaysia. Their study indicated that only a negligible portion of Islamic bank financing is strictly PLS based. Moreover, they concluded that Islamic deposits were not interest-free, but were closely pegged to conventional deposits rates. Husin (2015) measured the pace and magnitude of transmission via profit rate channel for Islamic banks versus interest rate channel of conventional banks. They indicated that the pass-through to Islamic banks was high and sizable. Husman (2015) also compared the monetary transmission through Islamic and conventional banks by investigating how a particular bank asset portfolio determined the equilibrium rate of return on loans and on deposits. Their results showed no significant difference in responses of the two types of banks to the central bank policy rate. However, the difference becomes apparent and significant after excluding Islamic windows from the sample.

The survey indicates a broader consensus that the Islamic banks behave similar to the conventional banks on facing policy shock. On the question; why Islamic banks functioning is unexpectedly influenced by the interest rates, Weill 
(2011) observed that the Islamic banks in general have a lower market power than conventional banks which affect their ability to influence the price of products when competing with their conventional counterparts. Ariss (2010) using different measures of competition also concluded that Islamic banking was less competitive compared to their conventional counterpart. It was not surprising to them that the price setting behavior of Islamic banks were mimicking the conventional banks in competitive environment. Khan (2010), Ming-Hua Liu (2009) and Obaidullah (2005) argued that Islamic financial institutions face "withdrawal risk" in deposit market had it offered lower rate of return compared to what its competitor paid. This situation was not very different from the loan market where Islamic banks were competing with the conventional banks for winning market share.

Kuran (1993) predicted long ago that the problems of moral hazard and adverse selection would force Islamic Banks to look alike the conventional ones. El Gamal (2006) also argued that the Islamic financial markets had to deal with the allocation of financial credit and risk similar to conventional financial markets and consequently, due to this functional necessity, will mimic conventional finance as closely as possible.

Additionally, the literature on Islamic transmission mechanism has documented the degree of sensitivity of Islamic finance to the interest rate. Ergec and Arslan (2013) and Kassim et al., (2009) argued that the Islamic banks were more sensitive to the changes in interest rates compared to the conventional banks because they were operating in shallow financial markets. Sukmana and Kassim (2010), found that Islamic deposits responded negatively to the shock in interest rates in Malaysia.

Despite the consensus on the effect of policy shock, the literature is in less agreement on the impact of the excess liquidity present in the Islamic banks on their price setting behavior. A salient feature of Islamic banks around the world is that they are often surplus in liquidity. Khatat (2016) notes that the prohibition on interest rates; insufficient sterilization; lack of Sharia-compliant assets and insufficiently developed Islamic financial markets are the key reasons for this surplus liquidity. Though literature on conventional transmission mechanism has documented the deleterious effect of excess liquidity, this assessment for Islamic bank remains overdue as empirical research on this topic is clearly missing. Iqbal and Molyneux (2005) asserted that "excess liquidity" was not a correct way of characterizing Islamic financial institutions since they cannot turn to the interbank market or to the central bank to borrow short-term funds on facing a temporary liquidity crunch, as these are interest-based transactions. Therefore, the institutions have to have greater liquidity than non-Islamic ones. On the contrary, Iqbal (1998) suggested that only 6 Islamic banking scholars said that "excess Liquidity" was "not a problem" when 60 of them surveyed. Moreover, 28 of 60 surveyed felt that the excess liquidity was a serious problem for some or all Islamic banks.

Very few studies opted to work on the spillover effect between the conventional and the Islamic banks. Notably, Ergec and Arslan (2013) argue that returns of Islamic bank deposits are likely to be affected by interest rates of conventional deposits. Bacha (2004), Chong and Liu (2009) and Cevik and Charap (2011) find causality between return on Islamic deposits and conventional deposit rates. The findings in these studies indicate that Islamic bank return rates are affected by 
conventional deposit rates. Moreover, empirical result of Ben Amar et al. (2015) suggest that though conventional and Islamic banks react to each other, the reaction of conventional banks to a shock on the financing provided by Islamic banks seems to be more significant than the reaction of Islamic banks to a shock on the conventional banks credit. Therefore, our study makes an important contribution by studying the price spillover between the two systems and impact of excess liquidity on the price setting behavior and its spillover between the conventional and Islamic banks.

\section{METHODOLOGY}

\subsection{Data}

This study uses monthly data from January 2004 to October 2016. For practical purposes, excess liquidity is reported as a ratio of excess fund, including eligible securities with banks, above what is required statutorily to the time and demand liabilities of the banks. Mohanty (2006) advocates for including short term government securities in definition of excess liquidity, which is also being practiced by the most of the central bank. ${ }^{18}$

Figure 3.

\section{Weighted Average Lending Rates}

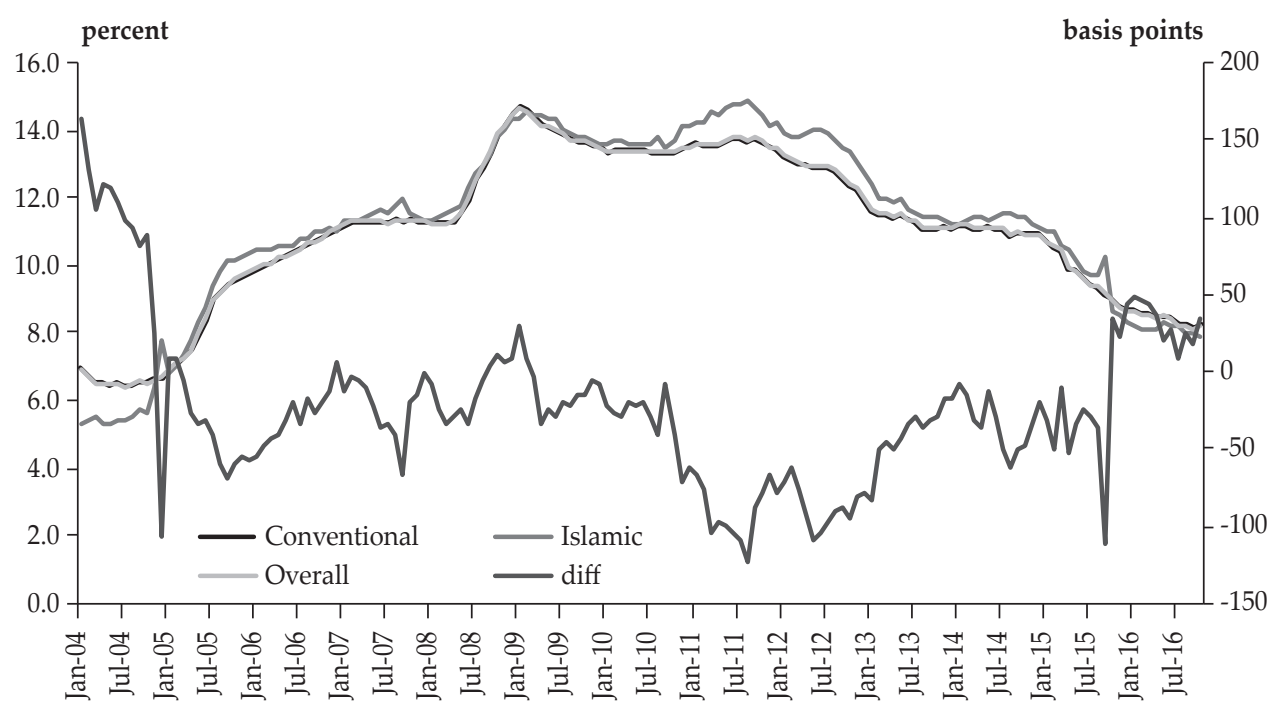

A consistent series of net time and demand liabilities was available from December 2005 only. Fragmented and inconsistent information on this variable was available for a few months before December $2005 .{ }^{19}$ For example, data from

18. Data Note 1 on the details the usefulness of this definition is available at the working paper version of this paper, available at: http://www.sbp.org.pk/publications/wpapers/2018/wp100.pdf

19. Working paper version provides more detail of the issue in Data Note 2 . The working paper is available at: http://www.sbp.org.pk/publications/wpapers/2018/wp100.pdf 
$23^{\text {rd }}$ April 2005 to $24^{\text {th }}$ December 2005 was missing. Missing data were reconstructed using liquidity ratio. Liquidity ratio was regularly reported by the central bank for individual banks and as a banking sector aggregate. This ratio was defined as the liquidity maintained in specified proportion to the time and the demand liabilities. Following the practice in literature, this study used the 6-month repo rate as a proxy for the SBP policy rate.

\section{Lending and Deposit Rates}

Weighted average lending and deposit rates are acquired separately for Islamic and conventional banks from State Bank of Pakistan. SBP publishes aggregate weighted average lending and the deposit rates for the banking sector of Pakistan, without identifying the conventional and Islamic banks. Structurally, Islamic banks are different from the conventional banks and the price setting mechanism in the two sectors should be different, at least theoretically. However, the aggregate retail rates reported by SBP masked the varying dynamics of the retail pricing in the two systems.

For example, Islamic banks initially offered discounted lending rate compared to the conventional banks to increase their market share (see Figure 3). However, as the Islamic finance quickly developed as an alternate mode, these banks started lending at higher rates compared to their peers. There could be a number of factors such as, expected interest rate risk, stringent regulatory requirements, lack of benchmark for lending and technical and management skills could have contributed to this change in the pricing behavior.

Figure 4 .

\section{Weighted Average Deposits Rates}

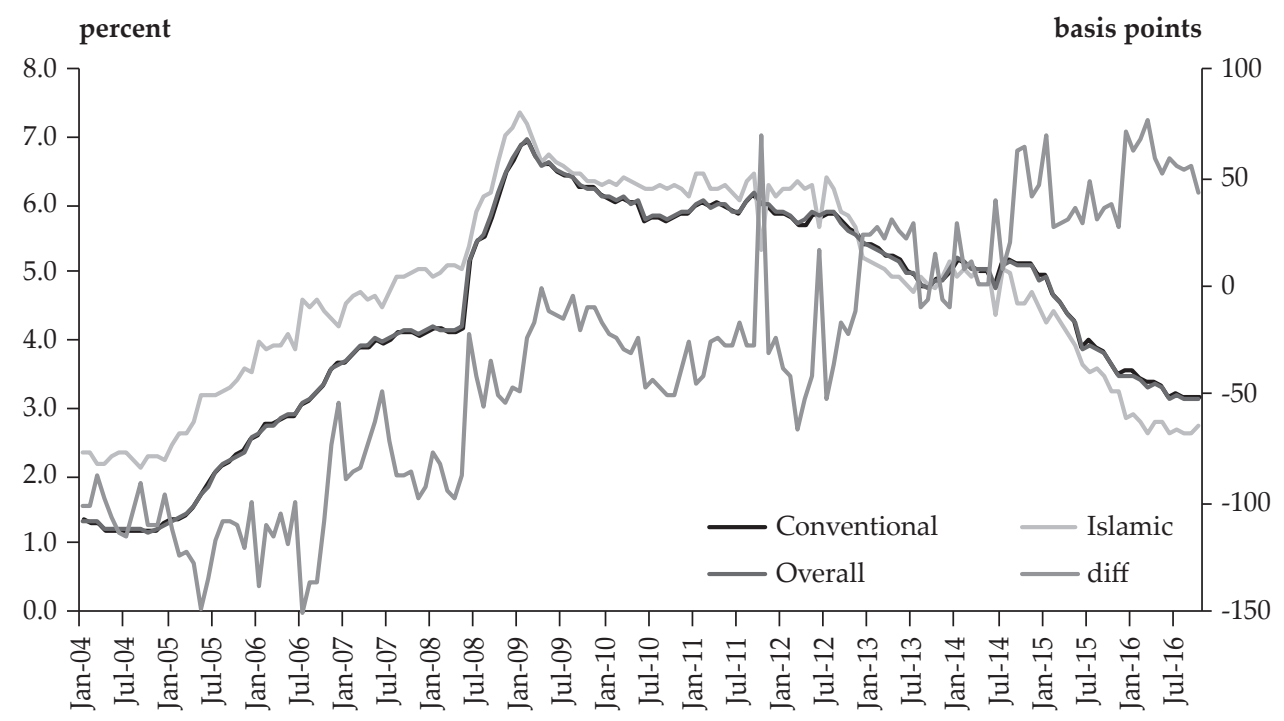


This situation is not very different from the deposit rate. Initially, Islamic banks were offering a higher deposit rates to woo the depositors however as the industry matured over the years, the premium on the deposit rate started to decline. Currently, Islamic banks are taking deposits at discount (conventional rate minus Islamic rate is negative) compared to that offered by the conventional banks (see Figure 4). Notably, SBP remained the prime source of data of this research.

\subsection{Methodology}

This study has adopted a more practical approach and assumed that the policy shocks affect the retail rates significantly, either directly (direct effect), when a bank changes its retail rates perceiving a positive policy shock will increase its borrowing cost. ${ }^{20}$ And/or indirectly (indirect effect), when a policy shock forces banks to manage their excess liquidity more efficiently resulting in an increase in the interbank lending rate. The retail lending and the deposit rates respond eventually. However, if demand for loanable funds is weak, fearing slowdown in the retail business, excess liquidity held by banks may prevent them from increasing the lending rate in proportion to the policy shock, (Omer et.al, 2015). Interbank liquidity, therefore, plays a role of 'mediator' as it mediates the indirect relationship between the policy shocks and the retail rates.

The variables involved in the model were subjected to unit root tests to ascertain the data generating process. The results, which will be discussed in Section 6, suggest that all the variables were following differenced stationary process. Therefore, Vector Error Correction Mechanism (VECM) methodology, as given by the Equation (1), is used for estimation of the long run relationship between the variables.

$$
\Delta z_{t}=\mu+\rho\left(y_{t-1}-\alpha-\beta x_{t-1}\right)+\sum_{k=1}^{n} \gamma_{k} \Delta z_{t-1}+\varsigma_{t}
$$

In equation (1), $z_{t}$ is the vector of regressors $z_{t}=\left(x_{t}, y_{t}\right)^{\prime}$, where $y_{t}$ is the retail rates and $x_{t}$ includes explanatory variables such as policy rate and the excess liquidity, where necessary; $\rho$ is a loading vector and measures the speed of adjustment; $\beta$ is the cointegration vector; $\gamma_{k}$ short run adjustment coefficients and; $n$ is the number of lags chosen using information criteria. As for the existence of a long run, relationship $\rho$ must be significantly different from zero. The coefficient $\beta$ shows the long run relationship between the regressors. In this context $\beta$ $=1$, indicates a complete pass through of regressors to the dependent variable provided both $x_{t}$ and $y_{t}$ have same unit of measurement. Alternatively, $\beta<1$ implies incomplete pass through.

The long run VECM coefficient provides estimate of the pass-through of the policy rate. When excess liquidity is included as a regressor, its coefficient is less meaningful in quantifying its impact on the pass though of the policy rate, as the former becomes a conduit to the transmission of policy between the

20. Recently, Jamilov and Égert (2014) have also used similar approach. 
two regressors. A change in the policy rate is likely to affect the excess liquidity holdings of the banks, at least theoretically, while disturbing their retail rates. Therefore, previously, a negative sign with the liquidity coefficient is used as a qualitative indicator of its impeding effect on the pass through of the policy rate.

This study aims to first quantify the impact of excess liquidity on pass-through of the policy rate to the retail rates using mediator approach. The mediator or indirect effect, in this research, is estimated using the long run $\beta$ coefficient from VECM (see Figure 5). ${ }^{21}$

\section{Mediating Effect}

Figure 5.

Excess Liquidity with Mediator Effect

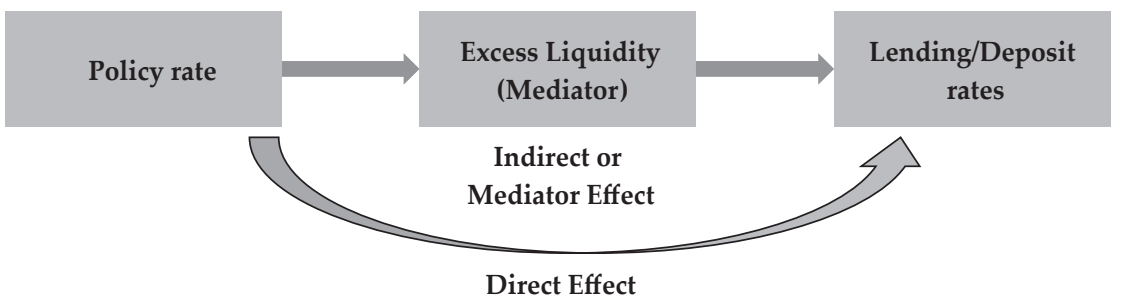

Literature documented two approaches, Judd and Kenny (1981) and Sobel (1982), for estimating mediator or indirect effect. This study benefits from Judd and Kenny (1981)'s approach for its simplicity. In this approach, impact of excess liquidity (mediator effect shown by Equation 4) is estimated by differencing the coefficients of the key policy variable (i.e., policy rate), when the excess liquidity is included in (Equation 2) and then excluded (Equation 3) from the model, as shows below. ${ }^{22}$

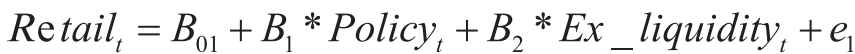

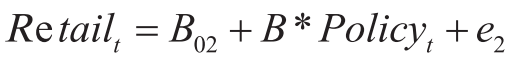

The mediator effect: $\quad B_{\text {mediator }}=B-B_{1}$

21. If the direction is known a priori, one can estimate the long run relationship using Dynamic OLS procedure.

22. In Sobel (1982) approach, mediator effect is calculated as $B_{\text {mediator }}=(B)\left(B_{2}\right)$. Despite differences, the results of the two approaches are very similar. 


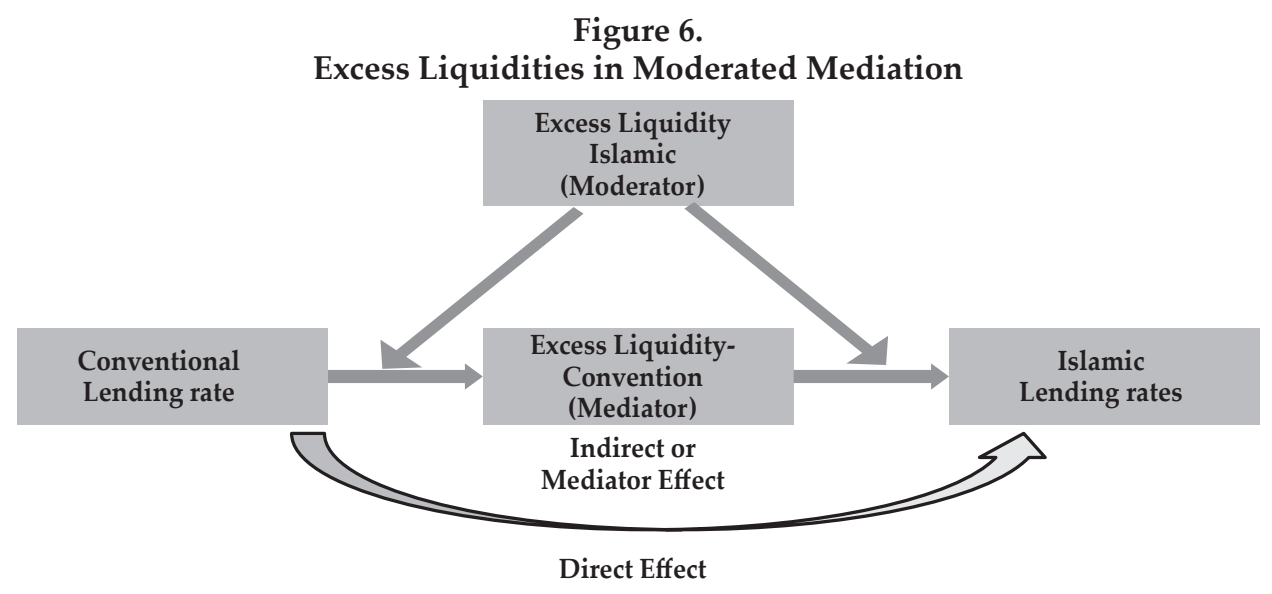

Interestingly, estimation of impact of the excess liquidity on the spillover between the retail rates of the two systems is more complicated as nature of excess liquidity present in such systems is very different. Therefore, a more holistic moderated-mediation approach is used to capture the impact of excess liquidity on the price spillover between the two systems.

\section{Moderated-Mediation Effect}

A moderator is a variable that may strengthen or weaken an economic relationship between two variables. ${ }^{23}$ In a more complicated setting, a mediator variable can be moderated by another variable that may or may not be similar in nature. A moderated-mediation is, therefore, a process where economic relationship between the two variables is mediated by a third variable, while performance of the mediator itself is influenced by some other moderator variable.

For example, the relationship between the retail lending rates of the two systems is influenced by the excess liquidities present in the two systems, involving different dynamics (see Figure 6). Existing literature is not very helpful in guiding mediation or moderation nature of these excess liquidity in intermediation between the retail rates. For simplicity, this study assumes one of these liquidities acts as a mediator while other act as a moderator while transmitting the shock between the retail rates of the two system.

Assuming that variables $\mathrm{W}$ and $\mathrm{M}$ respectively are moderator and mediator (both being excess liquidities in the two systems) for explaining the relationship between the retail rates (say $\mathrm{X}$ and $\mathrm{Y}$ or policy and retail rates) of the two systems, the mediation-moderation effect can be obtained from long run coefficients obtained from Equation (1), as shown by Equation (7). It provides the quantitative impact of excess liquidity on the price spillover between the Islamic and conventional banks.

23. A basic moderator effect can be represented as an interaction between a focal independent variable and a factor that specifies the appropriate conditions for its operation. 


$$
\begin{aligned}
& M=\alpha_{01}+\alpha_{1} X+\alpha_{2} W+\alpha_{3}\left(W^{*} X\right)+e_{1} \\
& Y=\beta_{01}+\beta_{1} M+\beta_{2} X+\beta_{3} W+\beta_{4}\left(W^{*} X\right)+\beta_{5} M W+e_{2}
\end{aligned}
$$

Indirect effect: $\left(\beta_{1}+\beta_{5} W\right) *\left(\alpha_{1}+\alpha_{3} W\right)$

\section{RESULT AND ANALYSIS}

As indicated earlier, the variables are subjected to the unit root tests. The results are provided in Table A3 in Appendix. Since variables involved were differenced stationary, VECM applied to estimate both the long run relationship and short run dynamics. This study, however, focuses mainly on the long run pass-through, as policy shocks are expected to bring permanent change in the nominal retail variables.

Table 1 and Table 2 shows the long run pass-through of the policy rate to the retail rates for the conventional and Islamic banks, respectively in a nested setting i.e., by excluding and then including excess liquidity. No. of lags, in the tables, indicate the optimal lags selected using Hannan-Quinn (HQ) criteria. The number of $\mathrm{CE}$ indicates the number of cointegrating relationship identified by Johanson's Rank test, the details of which can be provided on request. Most of the models appear to have one cointegration relationship, except model (6) and (12). Both models include excess liquidity, which makes presence of two-cointegration relationship possible.

The upper panels of the tables describe the estimates of the error correction coefficient. A significant coefficient suggests that the long run relationship exists between the variables, where dependent variable adjusts toward equilibrium in response to the shock to the system. The lower panels of the tables show estimates of the long run relationship. 'Liquidity effect', at the bottom of the tables, indicates the mediation effect of excess liquidity on the pass-through of the policy shock to the retail rates. The results of the diagnostic tests, provided in Table A4 in Appendix A2, suggest that residuals of the estimated models are mostly uncorrelated, however they are not normally distributed, which is expected given the small size of the sample. ${ }^{24}$ Moreover, test for stability of the selected model suggests that the number of stationary cointegration equation correctly identified. In the following sub-section, estimated results are discussed separately for the conventional banks, Islamic banks, and spillover effect of price between the two banking systems.

\section{Monetary Policy Pass-Through in Conventional Banks}

Table 1 shows the pass-through of the policy rate to the retail rates for conventional banks in a nested setting where excess liquidity was dropped initially [models i.e., (1) \& (3)] and included later [models (2) \& (4)]. Interestingly, the estimates

24. Presence of serial correlation is tested using Portmanteau Q-statistic using 12 lags. The null hypothesis of the test is; residuals are not serially correlated. The normality test is conducted using Shapiro-Wilk test. The null hypothesis for test is that the residuals are normally distributed. Eigen Value (EV) Stability test indicates whether the number of cointegrating equations is misspecified or whether the cointegrating equations, which are assumed to be stationary, are not stationary. 
of model (1), pinpointing the policy and lending rate relationship, indicates that the adjustment coefficient of the former is significant while that of the latter is insignificant, at five percent level. This result suggests that the policy rate, instead of the lending rate, adjusts significantly towards equilibrium in response to the shock to the system. Previous studies, e.g., Fazal and Salam (2013), Hanif and Khan (2012) and SBP (2005) using aggregate data, reported a significant impact of the policy rate on the lending rate. Perhaps, evolving dynamics of the Islamic banks, included in the aggregate data, may have contributed to this deviation from the earlier result. Therefore, an aggregate picture of pass-through may not be very reliable if objective is to bring policy change in the conventional banks alone. As conventional banks preferred risk free securities in wake of strong borrowing demand from government, their lending becomes less dependent on the policy rate. Possibly, conventional bank anticipates a change in the policy rate a priori due to their focus on the government borrowing, and in response, they proactively change their retail lending rate ex ante.

Table 1.

Discount Rate's Long Run Pass-Through to Retail Rates of Conventional Banks

\begin{tabular}{lcccc}
\hline Dependent Variable & \multicolumn{2}{c}{ Lending Rate } & \multicolumn{2}{c}{ Deposit Rate } \\
\hline Model \# & $\mathbf{1}$ & $\mathbf{2}$ & $\mathbf{3}$ & $\mathbf{4}$ \\
No. of CE & $\mathbf{1}$ & $\mathbf{1}$ & $\mathbf{1}$ & $\mathbf{1}$ \\
No. of Lags & $\mathbf{3}$ & $\mathbf{3}$ & $\mathbf{2}$ & $\mathbf{1}$ \\
\hline CE_(lending/Deposit rate) & -0.0115 & $-0.0468^{*}$ & $-0.0759^{*}$ & $-.07694^{*}$ \\
& {$[0.574]$} & {$[0.019]$} & 0 & {$[0.000]$} \\
CE_Policy rate & $0.2205^{*}$ & $0.1632^{*}$ & 0.0979 & -0.0574 \\
& {$[0.003]$} & {$[0.029]$} & {$[0.149]$} & {$[0.150]$} \\
CE_Excess Liquidity & & 0.1203 & & -0.1044 \\
& & {$[0.720]$} & & {$[0.535]$} \\
\hline Policy Rate & $0.855^{*}$ & $0.8140^{*}$ & $0.6099^{*}$ & $0.5882^{*}$ \\
& {$[0.001]$} & {$[0.000]$} & {$[0.000]$} & {$[0.000]$} \\
Excess Liquidity & & $-0.0371^{*}$ & & $-0.0632^{*}$ \\
& & {$[0.009]$} & & {$[0.003]$} \\
Liquidity Effect & & $0.0107^{* *}$ & & 0.0162 \\
& & {$[0.069]$} & & {$[0.106]$} \\
\hline
\end{tabular}

Number of lag selected using HQ criteria. P-values are in parenthesis. * and ${ }^{* *}$ shows 5-, and 10- percent level of significance. No. of CE shows the number of cointegrating relationship identified by Johanson's Rank test. No. of lags indicates the optimal number of lags selected using Hannan-Quinn (HQ) criteria. Both lending and the deposit rates, we used nested models when excess liquidity was dropped initially from the model (i.e., Model (1) \& (3)) and later included (models (2) \& (4)). Liquidity effect shows the Mediation Effect.

However, when the effect of excess liquidity is controlled as shown in model (2), transmission of policy shock reappears in both directions indicating that both lending and policy rates adjust toward the long run equilibrium in wake of the shock given to the system. The lending rate falls back while policy rate moving 
up towards the new equilibrium. Almost 0.81 percentage point of the shock to the system passes to the lending rate in the long run in a liquidity controlled environment.

Models (3) and (4) indicate pass-through of the policy rate to the deposit rate. The estimates suggest that the deposit rate adjusts in response to the shock to the system, independent of the presence of the excess liquidity. Imposition of the regulatory deposit rate, benchmarked with the policy rate, has strengthened the direction of the pass-through to the deposit rate. ${ }^{25}$ Estimates of the lower panel suggest that almost 0.60 percentage point of the monetary policy shock passes to the deposit rate in the long run. Moreover, negative signs with this coefficient of the excess liquidity [in Models (2) \& (4)] suggest that it impedes the pass-through of the policy rate in the conventional system.

Our results on lending and deposit rate pass-though is not very different from that reported in the available literature on Pakistan (Table A5 in Appendix). ${ }^{26}$ The marginal difference is driven not only by the variation in time but also the data definition used. Earlier studies have used aggregate retail rates of the banking sector while this study has used information specific to the conventional and the Islamic banks.

Interestingly the coefficient for the 'liquidity effect' at the bottom of the table, quantifying its impact, is found weakly significant. This result suggests that excess liquidity is mediating the policy rate's pass-through to the retail rates, though its impact is weak. Around one percentage point of the shock passes through excess liquidity to retail rates. The impact is clearer for the lending rate than the deposit rate primarily due to the conventional banks substantial investment in the government securities.

\section{Monetary Policy Pass-Through in Islamic banks}

Table 2 pinpoints the pass-through of the policy rate to the returns (on financing and investment) in the Islamic banks. Estimates of Model (5) suggest that both return on financing (or lending rate) and the policy rate adjust towards equilibrium. However, when excess liquidity is controlled [in Model (6)], only return on financing adjusts towards long run equilibrium. The estimates of the long run relationship at the lower panel of the table suggests that almost 0.84 percentage point of unit shock to the system passes to the return on financing (lending rate) in the long run, which increases to 0.92 percentage point in liquidity controlled environment. This results show that the pass through of the policy rate to the return on Islamic financing is not similar to conventional banks. In the latter, the pass-through was not detected between the policy and retail rates until excess liquidity present in the system was controlled. The influence of policy rate on the Islamic bank's financing rate is not unexpected as the central bank's regulation

25. SBP imposed regulatory deposit rate on conventional banks from June 012008 to improve the passthrough to the deposit rate. SBP linked the minimum deposit rate, to be paid to a depositor, with SBP repo rate.

26. We borrowed Table A5, in Appendix, from Omer (2016) which summarizes the available literature on monetary policy pass-through of policy rates to the retail rates, in Pakistan. 
forces the Islamic banks to benchmark their lending with the KIBOR (see Chapter 2 for details).

Model (7) and (8) shows the estimates of pass-through for the return on investments (deposit rate) in Islamic banks. The estimates of upper panel suggest that both policy rate and the return on investment (deposit rate) significantly adjust towards the equilibrium in response to the shock to system, independent of the presence of excess liquidity. Estimates of the long run relationship in the lower panel of the table suggest that almost 0.57 percentage point of the shock to the policy rate passes to the return on investment (deposit rate). Not surprisingly, the relationship between the return (deposit rate) and the policy rate in Islamic banking system is similar to the conventional banking system despite the fact that the price setting mechanism is completely different in the two systems. In conventional banks it is driven by the interest based regulatory requirement, while in Islamic system deposit rate is driven by the philosophy of profit sharing. Moreover, similar to the conventional system, sign of long run excess liquidity coefficients are negative indicating that it impedes the pass-through of the policy rate on the returns on investment however, its impact is surprisingly insignificant.

Table 2.

Discount Rate's Long run Pass-Through to Returns in Islamic Banks

\begin{tabular}{lcccc}
\hline Dependent Variable & \multicolumn{2}{c}{ Financing (Lending rate) } & \multicolumn{2}{c}{ Investment (Deposit Rate) } \\
\hline Model \# & $\mathbf{5}$ & $\mathbf{6}$ & 7 & $\mathbf{8}$ \\
No. of CE & $\mathbf{1}$ & $\mathbf{2}$ & $\mathbf{1}$ & $\mathbf{1}$ \\
No. of Lags & $\mathbf{7}$ & $\mathbf{1}$ & $\mathbf{2}$ & $\mathbf{1}$ \\
\hline CE_(Financing/Invetment rate) & $-0.1576^{*}$ & $-0.1632^{*}$ & $-0.1057^{*}$ & $-0.1684^{*}$ \\
& {$[0.000]$} & {$[0.000]$} & {$[0.025]$} & {$[0.000]$} \\
CE_Policyrate & $-0.1162^{*}$ & -0.0417 & $0.2563^{*}$ & $0.1609^{* *}$ \\
& {$[0.005]$} & {$[0.309]$} & {$[0.004]$} & {$[0.060]$} \\
CE_Excess Liquidity & & $0.5475^{*}$ & & 0.0045 \\
& & {$[0.033]$} & & {$[0.993]$} \\
\hline Policy rate & $0.8376^{*}$ & $0.9208^{*}$ & $0.5776^{*}$ & $0.5685^{*}$ \\
& {$[0.000]$} & {$[0.000]$} & {$[0.000]$} & {$[0.000]$} \\
Excess liquidity & & -0.0127 & & -0.0095 \\
& & {$[0.366]$} & & {$[0.291]$} \\
Liquidity Effect & & 0.018 & & -0.0064 \\
& & {$[0.284]$} & & {$[0.344]$} \\
\hline
\end{tabular}

Number of lag selected using HQ criteria. P-values are in parenthesis. ${ }^{*}$ and ${ }^{* *}$ shows 5-, and 10- percent level of significance. No. of CE shows the number of cointegrating relationship identified by Johanson's Rank test. No. lags indicate the optimal number of lags selected using Hannan-Quinn (HQ) criteria. Both for lending and the deposit rates, we used nested models when excess liquidity was dropped initially from the model (i.e., Model (1) \& (3)) and later included (models (2) \& (4). Liquidity effect shows the Mediation Effect.

At the bottom of the table, liquidity effect showing the long run mediation by excess liquidity is found insignificant. This result suggests that the presence of excess liquidity and its impact on the Islamic pass-through is mostly myth. 
Perhaps, Islamic banks have to manage their excess liquidity more efficiently as they do not enjoy the luxury of parking the excess reserve in government securities. Moreover, as suggested by Iqbal and Molyneux (2005), excess liquidity with the Islamic banks may not be 'in excess' given their intrinsic risk sharing structure and their limitation to turn to the interbank market or to the central bank to borrow short-term funds in case of a temporary liquidity crunch. Therefore, a general understanding of structure of the Islamic financial system and excess liquidity with them need to be improved significantly. Our result on the policy rate's pass-through in the Islamic bank is the first for Pakistan. However, our result finds support from [Chong and Liu (2009), Ergec and Arslan (2013), Khan (2010), Hasin and Majid (2015), Akhatova (2016), Husin (2015), Zaheer (2013) and Husman (2015)].

\section{Spillover Effect of Price between the Islamic and Conventional Banks}

Table 3 shows the spillover effect of retail prices (lending rate versus return on financing, and deposit rate versus returns on investment) between conventional and Islamic banking systems. Model (9) in Table 3 shows the long run relationship between the lending rates of conventional banks and return on investment of Islamic banks. The adjustment coefficients in the upper panel demonstrate that the return on financing adjusts to the shock to the equilibrium relationship between them. If the price system receives a shock, say by increase in the lending rate of the conventional banks, Islamic banks follow the conventional banks in pricing their lending products.

Islamic banks are relatively new phenomenon in the global financial landscape, which was previously dominated by the conventional banks. The fact that the Islamic banks follow the conventional banks in pricing the lending products is not surprising and confirms the findings of previous studies. Almost 0.97 percentage point of shock to the lending rate of conventional banks, shown in the lower panel of Table 3 [Model (9)], passes to the rate of return on financing from Islamic banks in the long run.

Surprisingly, the pass-through between the deposit rate and return on investment is not similar to that of the lending instruments, as shown in the upper panel of Table 3 [Model (11)]. In contrast, the result suggests that any shock to the deposit rate system leads to adjustment in the conventional bank deposit rate, instead of adjustment in return in investment of Islamic banks. Thus, in pricing deposit products, Islamic banks appear to have acquired the status of leaders, while the conventional banks have become followers. The response of conventional banks to the shock to the deposit system suggests that they, instead of the Islamic banks, suffer from the 'deposit withdrawal risk' contrary to the suggestion of Khan (2010) and others. Such an impact is also surprising given the conventional deposit rate is an administered rate. Administrative rate refers to lower bound for the deposit rate to be offered by conventional banks to the depositors. Perhaps, conventional banks are also focusing on the competitive Islamic deposit rate, besides offering the administrative rate. The Islamic banks are exempted from paying administered deposit rate. 
Intuitively, Islamic banks raises deposit on religious ground on promise that return on the investment will be in compliance with the Sharia requirement, which appeals people with religious inclination. Introduction of Islamic banks, therefore, channeled the savings of those who stayed away from banking system on interest prohibition. Therefore, Islamic banks should be credited with increasing the financial inclusion in the economy. Literature on economic growth suggests that increased financial inclusion leads to higher economic growth and lower income inequality in a society in the long run. Consequently, Islamic banks will promote economic growth and help mitigate the income inequality in the society.

Our result suggests that religion's connotation handed Islamic banks advantage in pricing deposit products, which also explains the lower return paid recently by the Islamic banks on investments (see Figure 3). The estimates of the lower panel suggest that the spillover between the two deposit rates is very strong and complete. More precisely, any shock to the return on investment in Islamic banks leads to a similar increase in the deposit rate of the conventional banks.

Besides the strong spillover between the prices, the results also demonstrate very strong effect of excess liquidities on the retail rates of the two system. For example, the result of Model (10) shows that any increase in the excess liquidity of the Islamic banks, say by one percentage point, decreases Islamic financing rate by 0.24 percentage point in the long run. However, if excess liquidity with the conventional banks increases with similar margin, the return on Islamic financing increases by 0.21 percentage point. Increase in the conventional excess liquidity means increased stock of government securities, which conventional banks accumulate to earn higher risk free return. As Islamic banks have limited investment opportunities, the conventional bank investment in the government securities is perhaps supplemented by the liquidity from the Islamic banks. This drain in the Islamic liquidity increases the return on financing in Islamic banks.

Similarly, the result of Model (12) suggests that increase in the excess liquidity with the conventional banks, say by one percentage point, deceases the deposit rate of the conventional banks marginally, by 0.03 percentage point. On the contrary, one percent increase in the Islamic excess liquidity leads to 0.01 percentage point increase in the deposit rate of the conventional banks. Perhaps, a higher flow of deposits to the Islamic banks induces the conventional banks to raise their deposit rate.

Table 3.

Retail Rates Rate's Long run Pass-Through between the Conventional and Islamic Banks

\begin{tabular}{lcccc}
\hline Dependent Variable & \multicolumn{2}{c}{ Lending (Financing) Rate } & \multicolumn{2}{c}{ Deposit (Investment) Rate } \\
\hline Model \# & $\mathbf{9}$ & $\mathbf{1 0}$ & $\mathbf{1 1}$ & $\mathbf{1 2}$ \\
No. of CE & $\mathbf{1}$ & $\mathbf{1}$ & $\mathbf{1}$ & $\mathbf{2}$ \\
No. of Lags & $\mathbf{3}$ & $\mathbf{2}$ & $\mathbf{2}$ & $\mathbf{1}$ \\
\hline CE_(Financing/Investment) & $0.1563^{*}$ & 0.0172 & 0.1216 & $0.1317^{* *}$ \\
& {$[0.001]$} & {$[0.251]$} & {$[0.139]$} & {$[0.070]$} \\
CE_Excess_Isl & & $-1.0231^{*}$ & & -0.2018 \\
& & {$[0.000]$} & & {$[0.813]$} \\
\hline
\end{tabular}


Table 3.

Retail Rates Rate's Long run Pass-Through between the Conventional and Islamic Banks (Continued)

\begin{tabular}{lcccc}
\hline Dependent Variable & \multicolumn{2}{c}{ Lending (Financing) Rate } & \multicolumn{2}{c}{ Deposit (Investment) Rate } \\
\hline Model \# & $\mathbf{9}$ & $\mathbf{1 0}$ & $\mathbf{1 1}$ & $\mathbf{1 2}$ \\
No. of CE & $\mathbf{1}$ & $\mathbf{1}$ & $\mathbf{1}$ & $\mathbf{2}$ \\
No. of Lags & $\mathbf{3}$ & $\mathbf{2}$ & $\mathbf{2}$ & $\mathbf{1}$ \\
\hline CE_(lending/Deposit rate) & 0.0084 & 0.0029 & $-0.1853^{*}$ & $-0.2258^{*}$ \\
& {$[0.702]$} & {$[0.694]$} & {$[0.000]$} & {$[0.000]$} \\
CE_Excess_Con & & 0.1115 & & 0.188 \\
& & {$[0.341]$} & & {$[0.739]$} \\
\hline Islamic Financing/Investment & & & $1.0248^{*}$ & $1.0196^{*}$ \\
& & & {$[0.000]$} & {$[0.000]$} \\
Con_Lending/Deposit rate & $0.9657^{*}$ & $0.9854^{*}$ & & \\
ExcessLiquidity_Islamic & {$[0.000]$} & {$[0.000]$} & & $0.0117^{* *}$ \\
& & $-0.2421^{*}$ & & {$[0.081]$} \\
ExcessLiquidity_Con & {$[0.000]$} & & $-0.0292^{*}$ \\
& & $0.2061^{*}$ & & {$[0.001]$} \\
\hline Liquidity Effect & {$[0.000]$} & & \\
Excess_con & & & $0.0200^{* *}$ \\
Excess_Islamic & -0.0003 & {$[0.044]$} \\
& & {$[0.911]$} & -0.0062 \\
& & $-0.1182^{*}$ & & {$[0.808]$} \\
\hline
\end{tabular}

Number of lag selected using HQ criteria. P-values are in parenthesis. * and ${ }^{* *}$ shows 5-, and 10- percent level of significance. No. of CE shows the number of cointegrating relationship identified by Johanson's Rank test. No. lags indicate the optimal number of lags selected using Hannan-Quinn (HQ) criteria. Both for lending and the deposit rates, we used nested models when excess liquidity was dropped initially from the model (i.e., Model (1) \& (3)) and later included (models (2) \& (4). Liquidity effect shows the Moderated -Mediation Effect.

The 'liquidity effect', reported at the bottom of the Table 3, indicates a mediatory role played by the liquidities in pricing of retail products. In absence of any guiding theory or literature, it is assumed that one of the liquidities is acting as a mediator while the other is acting as a moderator. The role of the liquidities is reversed to obtain a statistically significant relationship. The coefficients reported are liquidity effects only for the mediator variables.

For example, in model (10), the liquidity effect under excess liquidity of Islamic bank is significant at five percent level. This result indicates that when excess liquidity of Islamic banks is mediating (and excess liquidity of conventional bank is moderating), as almost 0.12 percentage point of the shock to the conventional lending rate passes to the return of Islamic financing, through the Islamic liquidity. When the role of the liquidity is reversed, i.e., excess liquidity of the conventional banks become mediator and that of Islamic banks becomes moderator, their impact become insignificant. 
Moreover, in model (12), the results demonstrate that the conventional excess liquidity mediates the spillover of the shock between the deposit rates of the systems, while the Islamic excess liquidity moderates this relationship. Almost, 0.02 percent of the shock to the deposit rate system passes to the conventional deposit rate through conventional excess liquidity.

\section{Is there any relationship between the excess liquidities?}

As discussed earlier, the excess liquidity plays crucial role in transmitting price shock between the two systems. A natural question arises: how are the liquidities related? It should be noted that any bi-directional relationship between the two liquidity is not expected by the Sharia scholars as well as the financial regulator due to Sharia restriction.

Table 4.

Long run Relationship b/w Conventional and Islamic liquidity

\begin{tabular}{lc}
\hline No. of CE & $\mathbf{1}$ \\
\hline No. of Lags & $\mathbf{1}$ \\
\hline CE_Excess_Conventional & $-0.0800^{*}$ \\
& {$[0.016]$} \\
CE_Excess_Islamic & $0.1695^{*}$ \\
& {$[0.001]$} \\
\hline Excess_Conventional & 1.000 \\
Excess_Islamic & $0.9184^{*}$ \\
& {$[0.000]$} \\
Trend & $0.0525^{*}$ \\
& {$[0.030]$} \\
\hline
\end{tabular}

P-values are in parenthesis. * and ** shows 5-, and 10- percent level of significance. No. of CE shows the number of cointegrating relationship identified by Johanson's Rank test. No. lags indicate the optimal number of lags selected using Hannan-Quinn (HQ) criteria.

Table 4 pinpoints the cointegration relationship between two liquidities. The upper panel of the table suggests that the liquidities in both systems adjust toward the long run equilibrium when the system is subjected to a shock. More precisely, excess liquidity with the conventional banks falls back while that of the Islamic banks rises to attain the long run equilibrium if the system receives a shock.

The long-run relationship at the lower panel of the Table 4 suggests that any shock to excess liquidity of the Islamic banks leads to almost 0.92 percentage point increase in the excess liquidity of the conventional banks in the long run. Such a one-on-one relationship is not anticipated as Islamic liquidity inflows to conventional system is not expected though conventional banks are allowed to invest in the Islamic banking instruments. Interestingly, the process of adjustment is slower for the conventional banks compared to the Islamic banks perhaps due to their huge asset size. 


\section{CONCLUSION AND RECOMMENDATION}

This study investigated the comparative pass-through of the policy rate to the retail prices, spillover between the prices of the Islamic and the conventional banking systems, and impact of excess liquidity on the relationships using Vector Error Correction Mechanism (VECM), on data from January 2004 to October 2016, acquired from State Bank of Pakistan. Moreover, this study also assessed the quantitative impact of the excess liquidity on the pass-through and the spillovers of prices using mediator- moderator approach. The results of this research contribute to existing literature in a number of ways.

First, the results of this research suggest that the monetary policy shock affects the retail prices of the Islamic banks similar to the conventional banks, confirming the findings of the earlier studies on this subject. Moreover, our result suggests that there is a strong spillover between the retail prices of the two systems. Precisely, any shock to the loan price system (between lending rate of conventional banks and return on Islamic financing) leads to almost similar increase in return on financing (lending rate) of the Islamic banks. A shock to the deposit price system (between deposit rate of conventional banks and returns on investment from Islamic banks) leads to 0.60 percentage point increase in the deposit rate of the conventional banks. The results show that Islamic banks have acquired the status of the leader in pricing of the deposit products, where the conventional banks have become the follower. This is unexpected and stands in sharp contrast to the findings in literature, which generally depicts Islamic banks as less competitive, and follow the conventional banks in retail product's price setting.

Intuitively, Islamic banks raise deposit on religious ground, complying Sharia requirements, which appeal people with religious inclination. Such people may have stayed away from banking on ground of riba (interest) prohibition. Introduction of Islamic banking, thus, may have helped in channeling these savings into the banking system. As a result, it also explains why Islamic banks continue to attract deposit recently, despite paying lower return on investments. Islamic banks, therefore, should be credited with the increasing the financial inclusion in Pakistan. Literature on economic growth suggests that increased financial inclusion leads to higher economic growth and lower income inequality in a society in the long run. Therefore, our results suggest that Islamic banks are promoting economic growth and helping in mitigating the income inequality in the society.

Second, the investigation into the impact of excess liquidity on the monetary policy pass-through suggests that the presence of excess liquidity impedes monetary policy pass-through in both systems, and significantly in the conventional system. Surprisingly, impact of excess liquidity is found insignificant for the Islamic banks contrary to contention in literature. Perhaps, Islamic banks manage their liquidity more efficiently, as they do not enjoy the luxury of parking their excess reserves in government securities. Therefore, argument by Iqbal and Molyneux (2005) finds support that Islamic excess liquidity may not be 'an excess' given their intrinsic risk sharing structure and their limitation to borrow short-term funds from interbank market or from the central bank on facing the temporary liquidity crunch. Therefore, a general understanding of structure of the Islamic financial system and excess liquidity with them need to be improved significantly. 
Third, though Islamic banks follow the conventional banks in pricing the lending products; the assessment of impact of excess liquidity on the price spillover highlights interesting pattern. Increase in the excess liquidity of the Islamic banks decreases, while that of the conventional banks increases the lending price of the Islamic banks. The positive impact of conventional excess liquidity on the Islamic lending price (rate) is intriguing and suggests that higher liquidity holding of the conventional bank is creating pressure upward pressure on the Islamic loan prices. It is possible only if increase in the conventional liquidity is causes a drain to the Islamic excess liquidity. It is important to note that the excess liquidity with the Islamic banks remains mostly in fungible cash reserves form with the central bank. On the contrary, the conventional excess liquidity remains mostly in the form of short-term government securities, as the central bank frequently intervenes in the interbank market and absorbs conventional cash liquidity through OMOs if this liquidity is favorable by the central bank.

The results hint at the possibility of the liquidity transmission from Islamic banks to the interest based short-term government securities. Perhaps, Islamic banks are lending to the conventional banks through some unrevealed mechanism, which drains their liquidity, while conventional banks invest borrowed money into the interest based short term government securities, which results in increase in the conventional excess liquidity. Nevertheless, this indirect lending to the government may have improved overall efficiency of the financial sector in Pakistan.

This is also true for the deposit price system, where Islamic banks lead the conventional banks in pricing the deposit products. Any shock to excess liquidity of the Islamic banks decreases while that of the conventional banks increases the deposit rate of the conventional banks. Positive relationship between the excess liquidity of the Islamic banks and the deposit rates of the conventional banks shows that the conventional banks, instead of the Islamic banks, suffer from the 'deposit withdrawal risk' contrary to the suggestion of Khan (2010) and others.

Finally, the liquidity effect helps reveal the crucial dynamics of excess liquidity with strong policy implications. Though excess liquidity with the Islamic banks has no effect on the Islamic pass-through of the policy shocks, the liquidity effect reveals that it in fact mediates transmission of conventional price shock to the return on the Islamic finance. The strong mediatory effect of the Islamic excess liquidity in lending price transmission compared to notional effect of conventional liquidity on deposit price transmission highlights that Islamic excess liquidity, being highly liquid, has greater potential to affect the market conditions adversely. In effect, it also explains the recent swings witnessed in the interbank call market in Pakistan. Therefore, this situation demands more attention from the central bank as it has potential to dilute the intended impact of the monetary policy shock. Moreover, the unexpected presence of long run relationship between the excess liquidities of the two systems also points to this prospect where Islamic excess liquidity may have overriding impact on the conventional policy transmission going forwards, as the size of the Islamic banking system grows.

Following caveats are in order. Islamic banks are relatively new, and their asset size is small compared to that of the conventional banks. This study did not account for the asset sizes of the two systems. Moreover, this study has limited its 
scope assuming that the impact of a shock would be symmetric which may not be the case. Asymmetric response of the shock may be investigated in future research.

\section{REFERENCES}

Agénor, P.-R., J. Aizenman, A. Hoffmaister (2004), "The Credit Crunch in East Asia: What can Bank Excess Liquid Assets Tell Us", Journal of International Money and Finance, 23: 27-49.

Akhatova, M., M. P. Zainal and M. H. Ibrahim (2016), "Banking Models and Monetary Transmission Mechanisms in Malaysia: Are Islamic Banks Different?", Economic Papers, Vol. 35(2):169- 183.

Ariss, R. T. (2010), "Competitive Conditions in Islamic and Conventional Banking: A Global Perspective", Review of Financial Economics 19: 101-108.

Bacha, O. I. (2004), "Dual Banking Systems and Interest Rate Risk for Islamic Banks", MPRA Paper No. 12763.

Baele, L., M. Farooq, and S. Ongena (2014), “Of Religion and Redemption: Evidence from Default on Islamic Loans", Journal of Banking \& Finance, 44: 141-159.

Ben Amar, A., N. Hachichab, and R. Saadallah (2015), "The Effectiveness of Monetary Policy Transmission Channels in the Presence of Islamic Banks: The Case of Saudi Arabia", International Journal of Business, 20(3):237-260.

Cevik, S., and J. Charap, (2011), "The Behavior of Conventional and Islamic Bank Deposit Returns in Malaysia and Turkey", IMF Working Paper No. WP/11/156.

Chong, B. S., and Liu, M.-H. (2009). "Islamic Banking: Interest-free or Interestbased?", Pacific-Basin Finance Journal, Vol. 17, pp. 125-144.

Egert, B., and R. MacDonald (2009), "Monetary Transmission Mechanism in Central and Eastern Europe: Surveying the Surveyable", Journal of Economic Surveys, 23(2): 277-327.

El Gamal, M.A., (2006), Islamic Finance: Law, Economics and Practice, Cambridge University Press, New York.

Ergeç, E. H., and B. G. Arslan (2013), "Impact of Interest Rates on Islamic and Conventional Banks: The Case of Turkey", Applied Economics, 45:17, 2381-2388.

Fazal, S. K., and M. A. Salam (2013), "Interest Rate Pass-Through: Empirical Evidence from Pakistan", The Lahore Journal of Economics, 18(1): 39-62.

Gigineishvili, N. (2011), "Determinants of Interest Rate Pass-Through: Do Macroeconomic Conditions and Financial Market Structure Matter?" IMF Working Paper No.WP/11/176.

Hanif, N., and M.H. Khan (2012), "Pass-Through of SBP Policy Rate to Market Interest Rates: An Empirical Investigation", MPRA Paper No. 39587.

Hasin, Z., and M. S. A. Majid (2015), "The Importance of the Islamic Banks in the Monetary Transmission Mechanism in Malaysia", In El-Karanshawy, H. A., A. Omar, T. Khan, S. S. Ali, H. Izhar, W. Tariq, K. Ginena, and B. Al Quradaghi (Eds.), Islamic Economics: Theory, Policy and Social Justice, Volume 2, Bloomsbury Qatar Foundation Journal: A Member of Qatar Foundation.

Husin, M. M. (2013), “Efficiency of Monetary Policy Transmission Mechanism Via Profit Rate Channel for Islamic Banks in Malaysia", Journal of Contemporary Issues in Business Research, Vol. 2(2): 44-55. 
Husman, J., (2015), Essays on Banking and Monetary Policy in the Presence of Islamic Banks, PhD Dissertation, Department of Economics, University of Warwick.

Iqbal, M., A.Ahmad, and T.Khan (1998), "Challenges Facing Islamic Banking", Islamic Development Bank, Islamic Research and Training Institute Occasional Paper\#1. http://www.irtipms.org/PubDetE.asp?pub=80

Iqbal, M., and P. Molyneux, (2005), Thirty Years of Islamic Banking: History, Performance and Prospects, Palgrave Macmillan, Basingstoke, UK.

Jamilov, R., and B. Égert, (2014), “Interest Rate Pass-through and Monetary Policy Asymmetry: A Journey into the Caucasian Black Box", Journal of Asian Economics, 31-32: 57-70.

Judd, C. M., and D. A. Kenny, (1981), "Process Analysis: Estimating Mediation in Treatment Evaluations", Evaluation Review, 5: 602-619.

Kassim, S., M. A. Majid, and R. M. Yusof, (2009), “Impact of Monetary Policy Shocks on Conventional and Islamic Banks in a Dual Banking System: Evidence from Malaysia", Journal of Economic Cooperation and Development, 30, 41-58.

Khan, F. (2008), “Islamic Banking by Judiciary: The 'Backdoor' for Islamism in Pakistan?", South Asia: Journal of South Asian Studies, 31(3): 535-555.

Khan, F., (2010), "How 'Islamic' is Islamic Banking?", Journal of Economic Behavior E Organization, 76: 805-820

Khatat, M. H. (2016), "Monetary Policy in the Presence of Islamic Banking", IMF Working Paper \#WP/16/72, IMF, Washington D.C.

Khawaja, I., and S. Khan (2008), "Pass-through of Change in Policy Interest Rate to Market Rates", The Pakistan Development Review, 47(4), pp.661-674.

Kuran, T., (1993), “The Economic Impact of Islamic Fundamentalism”, In: Marty, M.E., Appleby, R.S. (Eds.), Fundamentalisms and the State: Remaking Polities, Economies, and Militance. University of Chicago Press, Chicago, pp. 302-341.

Lucchetta, M. (2007), “What Do Data Say About Monetary Policy, Bank Liquidity and Bank Risk Taking?", Economic Notes by Banca Monte deiPaschi di Siena SpA, 36(2):189-203.

Mohanty, M. S., G. Schnabel, and P. Garcia-Lima (2006), "Banks and Aggregate Credit: What is New?", In: The Banking System in Emerging Economies: How much Progress has been Made? BIS Papers No.28.

Mohsin, H.M. (2011), "Impact of Monetary Policy on Lending and Deposit Rates in Pakistan: Panel Data Analysis", The Lahore Journal of Economics, 16, pp.199-213.

Nissanke, M., and E. Aryeetey (1998), Financial Integration and Development: Liberalization and Reforms in Sub-Saharan Africa. London: Routledge,

Obaidullah, M., (2005), Rating of Islamic Financial Institutions: Some Methodological Suggestions, Working Paper: Islamic Economics Research Centre, King Abdulaziz University.

Omer, M., J. de Haan, and B. Scholtens (2015), "An Empirical Analysis of Excess Interbank Liquidity: A Case Study of Pakistan", Applied Economics, 47(44): 4754-4776.

Omer, M. (2016), “Should Central Bank Forget Reserve Requirements? Assessment of Reserve Requirements in Transmitting SBP's Policy Shocks to Retail Interest Rates and Exchange Rate", SBP Working Paper Series No. 81, SBP, Karachi. 
Ruffer, R., and L. Stracca (2006), "What is Global Excess Liquidity, and Does it Matter?", ECB Working Paper Series No. 696.

Qayyum, A., S. Khan, and I. Khawaja (2006), “Interest Rate Pass-through in Pakistan: Evidence from Transfer Function Approach", The Pakistan Development Review, 44(4 Part II), pp.975-1001.

Saxegaard, M. (2006) "Excess Liquidity and Effectiveness of Monetary Policy: Evidence from Sub- Saharan Africa", Working Paper No. 06/115, IMF, Washington.

SBP (2005), Performance of the Banking Sector, Pakistan: Financial Sector Assessment 2005. State Bank of Pakistan, Karachi.

SBP (2016), Quarterly Performance Review of the Banking Sector, Q3CY16, State Bank of Pakistan, Karachi.

Sobel, M. E. (1982)," Asymptotic Confidence Intervals for Indirect Effects in Structural Equation Models", In S. Leinhardt (Ed.), Sociological Methodology 1982 (pp. 290-312). Washington DC: American Sociological Association.

Sørensen, C.K., and T. Werner (2006), "Bank Interest Rate Pass-through in the Euro Area: A Cross Country Comparison," ECB Working Paper No. 580

Sukmana, R. (2015), "Economic Sectors Sensitivity to Islamic and Conventional Monetary Instruments: Case Study in Indonesia", In El-Karanshawy, H. A., A. Omar, T. Khan, S. S. Ali, H. Izhar, W. Tariq, K. Ginena, and B. Al Quradaghi (Eds.), Islamic Economics: Theory, Policy and Social Justice, Volume 2, Bloomsbury Qatar Foundation Journal: A member of Qatar Foundation.

Sukmana, R. and S. H. Kassim, (2010), "Roles of the Islamic Banks in the Monetary Transmission Process in Malaysia," International Journal of Islamic and Middle Eastern Finance and Management, 3: 7-19.

Weill, L. (2011), “Do Islamic Banks Have Greater Market Power?”, Comparative Economic Studies. 53: 291-306.

Zaheer, S., S. Ongena, and S.J.G. van Wijnbergen, (2013), "The Transmission of Monetary Policy through Conventional and Islamic Banks", International Journal of Central Banking, 9 (4): 175- 224. 


\section{APPENDIX}

Table A1.

Group-wise Composition of Banks

\begin{tabular}{cl}
\hline \multicolumn{1}{c}{ As of September 2016 } \\
\hline A. Public Sector Commercial Banks (5) \\
\hline 1 & First Women Bank Ltd. \\
2 & National Bank of Pakistan \\
3 & Sindh Bank Ltd. \\
4 & The Bank of Khyber \\
5 & The Bank of Punjab \\
\hline B. Local Private Banks (22) \\
\hline 1 & Al Baraka Bank (Pakistan) Ltd. \\
2 & Allied Bank Ltd. \\
3 & Askari Bank Ltd. \\
4 & Bank AL Habib Ltd. \\
5 & Bank Alfalah Ltd. \\
6 & BankIslami Pakistan Ltd. \\
7 & Burj Bank Ltd. \\
8 & Dubai Islamic Bank Pakistan Ltd. \\
9 & Faysal Bank Ltd. \\
10 & Habib Bank Ltd. \\
11 & Habib Metropolitan Bank Ltd. \\
12 & JS Bank Ltd. \\
13 & MCB Bank Ltd. \\
14 & MCB Islamic Bank Ltd. \\
15 & Meezan Bank Ltd. \\
16 & NIB Bank Ltd. \\
17 & SAMBA Bank Ltd. \\
18 & Silk Bank Ltd \\
19 & Soneri Bank Ltd. \\
20 & Standard Chartered Bank (Pakistan) Ltd. \\
21 & Summit Bank Ltd \\
22 & United Bank Ltd. \\
\hline C. Foreign Banks (4) \\
\hline 1 & Bank of Tokyo - Mitsubishi UFJ, Ltd. \\
2 & Ditibank N.A. \\
\hline
\end{tabular}


Table A1.

Group-wise Composition of Banks (Continued)

\begin{tabular}{cl}
\hline \multicolumn{1}{c}{ As of September 2016} \\
\hline D. Specialized Banks (4) \\
\hline 1 & Industrial Development Bank Ltd. \\
2 & Punjab Provincial Co-operative Bank Ltd. \\
3 & SME Bank Ltd. \\
4 & ZaraiTaraqiati Bank Ltd. \\
\hline & All Commercial Banks (31) \\
\hline & Include A + B + C \\
\hline & All Banks (35) \\
\hline
\end{tabular}

Source: SBP (2016)

Table A2.

Composition of Islamic Banking Institutions

\begin{tabular}{cl}
\hline \multicolumn{2}{c}{ Composition of Islamic Banking Institutions } \\
\hline Islamic Banks \\
\hline 1 & Al Baraka Bank (Pakistan) Ltd. \\
2 & Bank Islami Pakistan Ltd. \\
3 & Burj Bank Ltd. \\
4 & Dubai Islamic Bank Pakistan Ltd \\
5 & MCB Islamic Bank Ltd. \\
6 & Meezan Bank Ltd \\
\hline Conventional Banks having Islamic Banking Branches \\
\hline 1 & Askari Bank Ltd. \\
2 & Allied Bank Ltd. \\
3 & Bank Al Habib Ltd \\
4 & Bank Alfalah Ltd \\
5 & Faysal Bank Ltd. \\
6 & Habib Bank Ltd \\
7 & Habib Metropolitan Bank \\
8 & National Bank of Pakistan \\
9 & Silk Bank Ltd \\
10 & Sindh Bank Ltd \\
11 & Soneri Bank Ltd \\
12 & Standard Chartered Bank \\
13 & Summit Bank Ltd. \\
14 & The Bank of Khyber \\
15 & The Bank of Punjab \\
16 & United Bank Ltd. \\
& Grand Total 22 (6+16) \\
\hline
\end{tabular}

Source: SBP (2016) 
Table A3.

Unit root test results

\begin{tabular}{lcccc}
\hline & \multicolumn{2}{c}{ Augmented Dickey-Fuller test } & \multicolumn{2}{c}{ Philips-Perron test } \\
\hline & No trend & Trend & No trend & Trend \\
\hline Discount rate & -1.669 & -1.141 & -1.918 & -1.262 \\
Conventional banks & & & & \\
$\quad$ Lending rate & -1.734 & -1.629 & -1.531 & -0.647 \\
$\quad$ Deposit rate & -2.108 & -0.85 & -1.764 & -0.351 \\
$\quad$ Excess liquidity & -1.027 & -1.629 & -1.14 & -2.353 \\
$\quad$ Required reserves & & & & \\
Islamic banks & & & & \\
$\quad$ Lending rate & -1.681 & -1.498 & -1.972 & -1.012 \\
$\quad$ Deposit rate & -1.577 & -0.899 & -1.348 & -0.557 \\
$\quad$ Excess liquidity & -1.523 & -1.725 & -2.414 & -3.155 \\
$\quad$ Required reserves & & & & \\
\hline *5\% Critical Value & -2.887 & -3.445 & -2.886 & -3.443 \\
\hline
\end{tabular}

Notes: Augmented Dickey fuller test uses optimal lags to control the serial correlation, while Philips- Perron test applies non parametric Kernel to address the problem of the serial correlation. 


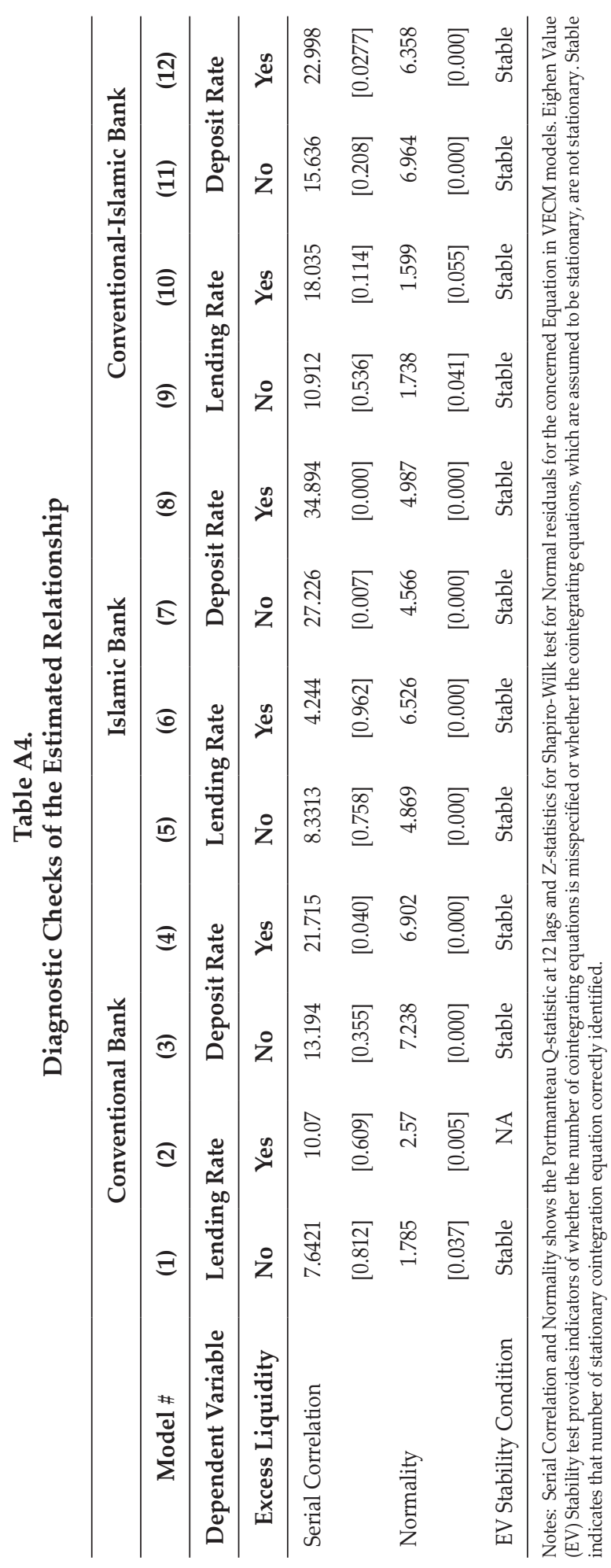


Table A5.

Literature on interest rate pass through to retail rates in Pakistan

\begin{tabular}{|c|c|c|c|c|c|c|c|}
\hline \multirow{3}{*}{ Study } & \multirow{3}{*}{ Period } & \multirow{3}{*}{ Instrument } & \multirow{3}{*}{ Method } & \multicolumn{4}{|c|}{ Pass through estimates } \\
\hline & & & & \multicolumn{2}{|c|}{ Short run } & \multicolumn{2}{|c|}{ Long run } \\
\hline & & & & $\begin{array}{l}\text { Lending } \\
\text { rate }\end{array}$ & $\begin{array}{c}\text { Deposit } \\
\text { Rate }\end{array}$ & $\begin{array}{l}\text { Lending } \\
\text { rate }\end{array}$ & $\begin{array}{c}\text { Deposi } \\
\text { Rate }\end{array}$ \\
\hline $\begin{array}{l}\text { Fazal and } \\
\text { Salam (2013) }\end{array}$ & 2005:06 - 2011:05 & 6-m TB rate & VECM & $0.3727^{*}$ & $0.3058^{*}$ & $0.887^{*}$ & $0.657^{*}$ \\
\hline $\begin{array}{l}\text { Hanif and } \\
\text { Khan (2012) }\end{array}$ & 2001:07 - 2011:08 & 1-wk KIBOR & ARDL & 0.3 & 0.13 & 0.91 & 0.64 \\
\hline Mohsin (2011) & 2001:11 - 2011:03 & $\mathrm{DR}$ & PC & 0.1 & 0.16 & 0.2 & Nil \\
\hline $\begin{array}{l}\text { Khawaja and } \\
\text { Khan (2008) }\end{array}$ & 1991:06 -2008:06 & TB rate & TFA & Nil & Nil & $0.43^{3}$ & 0.164 \\
\hline $\begin{array}{l}\text { Qayyum et al. } \\
\text { (2006) }\end{array}$ & 1991:03 -2004:12 & $\mathrm{TB}$ rate & TFA & Nil & 0.18 & $0.41^{2}$ & $0.223^{1}$ \\
\hline SBP (2005) & 1999:07-2006:06 & $\begin{array}{l}\text { TB cut-off } \\
\text { rate }\end{array}$ & ARDL & 0.198 & 0.044 & 0.987 & 0.444 \\
\hline
\end{tabular}

*significant at 5 percent.

TB: Treasury Bill, DR: Discount Rate, KIBOR: Karachi Interbank Offered Rate, ARDL: Auto Regressive Distributed Lags, TFA: Transfer Function Approach, PC: Panel Cointegration. VAR: Vector Auto Regression, VECM: Vector Error Correction Mechanism, Nil indicates no pass through detected.

${ }^{1}$ Pass through to the saving deposit rate (deposit with less than 6-month maturity), while long-run pass through takes around 3 years to complete. ${ }^{2}$ No short-run pass through and long-run pass through requires one and half to two years to complete. ${ }^{3}$ Longrun pass through requires one to one and half years. 4 Long-run pass through requires one year. 